\title{
MENYOROT FENOMENA CADAR DI INDONESIA
}

\author{
Fadhliah Mubakkirah
}

\begin{abstract}
Since the emergence of veil use in Indonesia, it has always been a hot issue to discuss, such as legal (Syariah) differences (khilafiyah issues), is it cultural or not, and it considered a symbol of radicalization. The most recent discourse is the ban on the use of the veil by the Minister of Religion to be polemic in the society, there are those who support with security reasons, and also those who reject it because they regard it as an expression of religious practice. The discussion about the use of veil became a response to the phenomenon that occurs in the community.
\end{abstract}

Keywords: Veil phenomenon, Bans of the veil, Radical indications.

\section{PENDAHULUAN}

November 2019 silam, masyarakat Indonesia kembali dihebohkan oleh wacana pelarangan cadar. Kembali, sebab kegaduhan masyarakat membicarakan cadar bukan kali pertama terjadi. Juga heboh, karena wacana ini sontak saja mendapat respon beragam dari masyarakat. Diperbincangkan dalam berbagai forum dan talk show, dengan beragam media, tulisan ataupun lewat kanal-kanal TV.

"Cadar adalah sebuah fenomena. Dalam ilmu sosial, setiap fenomena mempunyai makna, yang setiap orang tentu saja bisa memaknai. Pemaknaan dalam konteks ini bisa saja kita sebut sebagai sebuah tafsir. Tafsir tentang cadar tentu sudah banyak dilakukan, mulai dari yang bergaya ekstrem sampai yang moderat. Bahkan beberapa analisis ahistoris menyebutkan bahwa cadar bukan hanya atribut Islam an sich, namun umat agama lain juga menggunakan atribut cadar atau yang sejenisnya ini”, demikian ungkap Muhamad Mustaqim dilansir DetikNews (04/11/2019).

Wacana pelarangan cadar ini dilontarkan oleh Menteri Agama, Fachrul Razi. Ia menyampaikan hal tersebut dalam Lokakarya Peningkatan Peran dan 
31 | MUSA WA, Vol. 12 No.1 Juni $2020: 30-48$

Fungsi Imam Tetap Masjid di Hotel Best Western, Mangga Dua Selatan, Sawah Besar, Jakarta Pusat, Rabu (30/10/2019). Wacana pelarangan ini salah satunya dilatarbelakangi, ia muak dengan adanya anggapan sebagian orang yang menjadikan cadar sebagai ukuran ketakwaan. Ia mengatakan, akan menerapkan larangan tersebut di instansi pemerintah sebab adanya aturan pakaian seragam, serta adanya alasan keamanan.

Pro dan kontra lalu bermunculan terhadap wacana kebijakan Menteri Agama ini. Bagi yang mendukung kebijakan pelarangan cadar di instansi pemerintah, mereka beralasan bahwa pelarangan itu sah saja sebagai aturan, dan dimaksudkan untuk menjamin keamanan serta kebaikan ASN (Aparatur Sipil Negara) itu sendiri. Sedangkan bagi yang menolak, mereka beralasan bahwa larangan tersebut bertentangan dengan hak asasi manusia, menciderai konstitusi yang telah mengatur kebebasan dalam menjalankan agama, serta bertentangan dengan kebhinekaan yang dianut Indonesia. Oleh sebab itu, perlu kiranya mengkaji lebih jauh terkait cadar dan yang berkaitan dengannya. Dengan harapan, mampu memberi gambaran dan pemahaman kepada masyarakat luas. Sehingga mampu sedikit meredam kegaduhan, baik yang sedang terjadi ataupun meminimalisirnya di masa yang akan datang.

\section{PEMBAHASAN}

\section{Pengertian Cadar}

Cadar menurut KBBI adalah kain penutup kepala atau muka (bagi perempuan). Dalam intelektualisme Islam, istilah cadar yang dikenal di Indonesia sangat berkaitan dengan firman Allah:

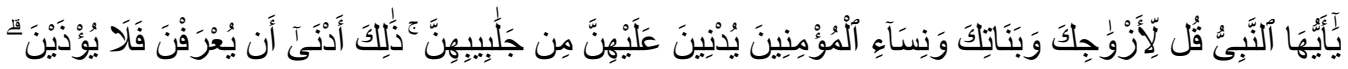

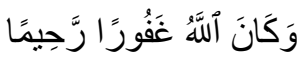

"Wahai Nabi, katakanlah kepada istri-istrimu, anak-anak perempuanmu dan istri-istri orang mukmin, "Hendaklah mereka mengulurkan jilbabnya ke seluruh tubuh mereka”. Yang demikian itu supaya mereka lebih mudah untuk dikenal, 
karena itu mereka tidak diganggu. Dan Allah adalah Maha Pengampun lagi Maha Penyayang". 1

Imam Ath-Thabary dalam mengomentari ayat ini, ia berkata bahwa para pakar tafsir berbeda pendapat mengenai sifat 'menjulurkan jilbab' yang diperintahkan Allah dalam ayat ini. Sebagian mereka mengatakan: yaitu dengan menutup wajahwajah mereka dan kepala-kepala mereka, dan tidak ditampakkan apa-apa kecuali hanya satu mata saja.

Memang, kata jilba $>b / j a l a>b i>b$ pada ayat ini tidak berarti penutup wajah. Namun dari ayat ini, ada ulama yang berpendapat, "menjulurkan jilbab ke seluruh tubuh" juga dengan menutup wajah. Sehingga pada praktiknya, ada kerudung yang menutupi semua kepala termasuk wajah (kerudung merangkap cadar). Ada juga kerudung yang dipakai terpisah dengan penutup wajah. Aksesoris penutup wajah ini yang kemudian disebut niqab, atau masyarakat Indonesia menyebutnya sebagai cadar.

"Niqab atau cadar adalah sesuatu yang digunakan perempuan untuk menutupi wajahnya. Kalau dikatakan: "wanita itu mengenakan niqab”, maka maksudnya ia sedang menutupi wajahnya dengan kain. Niqab adalah kerudung yang diletakkan perempuan di wajahnya sehingga tidak ada yang terlihat kecuali kedua matanya. Niqab terbuat dari kain, dan biasanya melekat pada kulit wajah perempuan. Tapi, niqab ini dilarang dipakai ketika sedang ihram (haji atau umrah)”, demikian tutur mantan Mufti Mesir, Prof. Dr. Ali Jum'ah. ${ }^{2}$

Dalam pandangan Prof. Dr. M. Quraush Shihab, cadar adalah pakaian yang digunakan untuk menutupi wajah, minimal untuk menutupi hidung dan mulut. ${ }^{3}$

Sedangkan menurut Ahmad Hilmi, Lc. MH.: "Cadar atau dalam bahasa Arab disebut niqab atau burqu', sebagaimana yang disebutkan oleh Ibn Mandzur di dalam kitabnya Lisan Al-'Arab adalah kain penutup yang biasa dipakai oleh

\footnotetext{
${ }^{1}$ QS. Al-Ahzab [33]: 59.

2 Ali Jum'ah, Menjawab Dakwah Kaum Salafi, Cet II (Jakarta Selatan, KHATULISTIWA

${ }^{3}$ Quraish Shihab, Wawasan Al-Quran..., h. 127.
} Press, 2017), h. 221. 
33 | MUSA WA, Vol. 12 No.1 Juni $2020: 30-48$

wanita untuk menutup wajah (bagian atas hidung) dan membiarkan bagian mata terbuka.

Nah, masalah model, tentu antar daerah dan negara akan berbeda-beda. Apalagi jika sudah berbicara selera, antara satu kepala dengan kepala yang lain sulit untuk sama.

Di Indonesia sendiri, perkembangan cadar sangat beragam. Hasil adopsi dari berbagai daerah dengan modifikasi. Selembar kain lebih kurang seukuran wajah dengan tali yang diikatkan melingkar kepala. Ada juga yang cukup diberi kancing untuk direkatkan di jilbab (khimar) utamanya. Ada juga yang dengan model jilbab dan cadar Saudi, cukup dengan selembar kain panjang yang sudah termasuk jilbab untuk penutup kepala dan rambut. Dan sisanya ditutupkan ke wajah sebagai cadar". 4

Sebagai pelengkap, ada beberapa istilah yang saling berkaitan dengan niqab/cadar. Berpagi-pagi penting untuk menuntaskan istilah-istilah tersebut. Jilbab dalam bahasa Arab/Al-Quran adalah baju kurung panjang atau gamis. Menurut Al-Jauhary, jilbab adalah milhafah yaitu kain yang sangat lebar, menutupi bagian atas termasuk wajah. Sedangkan jilbab menurut masyarakat Indonesia adalah istilah lain dari kerudung. Adapun kerudung, dalam bahasa Arab disebut khima $>r^{5}$. Lalu apa yang disebut cadar oleh masyarakat Indonesia, itulah $n i q a>b$ dalam bahasa Arab. Sedangkan hija $>b^{6}$ adalah perpaduan antara jilba $>b$ (kain lebar/baju kurung/gamis) dan khima $>r$ (kerudung). Sehingga istilah hija $>b$ syar'i yang acap kali terdengar, maksudnya adalah menutup aurat bagi wanita yang sesuai dengan tuntunan syariat. Yaitu memakai jilbab (gamis), khimar (kerudung) dan tanpa unsur tabarruj ${ }^{7}$.

“Kami juga perlu menegaskan kewajiban menutup aurat dan mengenakan hijab bagi perempuan. Hijab adalah pakaian yang digunakan untuk menutupi

${ }^{4}$ Ahmad Hilmi, Hukum Cadar Bagi Wanita, Cet I (Jakarta Selatan, Rumah Fiqih Publishing, 2019), h. 9.

${ }^{5}$ Baca QS: An-Nur [24]:31.

${ }^{6}$ Hijab secara bahasa berarti penutup, tabir, atau tirai. Dalam konteks pakaian, hijab adalah pakaian yang digunakan untuk menutupi aurat.

${ }^{7}$ Tabarruj secara bahasa berarti berhias, bersolek, atau memamerkan kecantikan. Makna pakaian wanita tanpa unsur tabarruj antara lain: tidak terlalu pendek, tidak terlalu sempit, dan tidak terlalu tipis. Baca QS: Al-Ahzab [33]:33. 
auratnya. Pakaian yang digunakan untuk menutupi aurat wajib memenuhi beberapa kriteria sebagai berikut:

1. Tidak boleh terlalu pendek sehingga membuat sebagian auratnya terlihat.

2. Tidak boleh terlalu sempit sehingga memperlihatkan lekuk-lekuk tubuh yang merupakan aurat.

3. Tidak boleh terlalu tipis sehingga bisa terlihat warna kulit dan anggota tubuh yang merupakan aurat.

Apabila pakaian perempuan -apapun namanya dan modelnya- telah memenuhi kriteria-kriteria di atas, maka ia bisa disebut dengan hijab syar'i. akan tetapi, apabila ada salah satu dari kriteria-kriteria di atas yang tidak terpenuhi, maka pakaian itu tidak bisa disebut dengan hijab syar' $i$ ". 8

Singkat kata, cadar adalah penutup wajah bagi kaum wanita. Baik yang menutupi wajah keseluruhan (di bagian mata, kain dengan tembus pandang), kecuali mata, atau hanya sebagian saja (sekadar hidung dan mulut/mulai di bawah mata menjulur ke bawah). Dengan beragam model,varian warna dan modifikasi.

\section{Cadar, Budaya Arab atau Syariat?}

Sejauh ini, setiap isu cadar muncul ke permukaan, akan berujung polemik; diperdebatkan di tengah masyarakat Indonesia. Hal ini disebabkan, antara lain, ada yang menganggap cadar sebagai budaya Arab dan ada pula yang menyatakan secara tegas bahwa cadar adalah bagian dari syariat Islam.

Sehingga bagi yang menganggap cadar merupakan budaya Arab, pelarangan penggunaan cadar menjadi hal yang wajar. Di antara alasannya, pertama, cadar adalah budaya dari Arab, dalam arti cadar bukan ajaran atau syariat Islam. Kedua, dalam soal pakaian, Indonesia sudah mempunyai budayanya sendiri. Kendati menurut penulis, alasan kedua ini terlihat tidak fair, sebab pada faktanya, pakaian ala Barat juga "membudaya" di Indonesia.

Di sisi lain, kelompok selanjutnya menyatakan bahwa cadar bukan budaya Arab. Baik berdasarkan fakta, penelitian ilmiah, ataupun dalil.

\footnotetext{
${ }^{8}$ Ali Jum'ah, op.cit., h. 227.
} 
35 | MUSA WA, Vol. 12 No.1 Juni $2020: 30-48$

Pada masa Jahiliyah dan awal masa Islam, wanita-wanita di Jazirah Arab memakai pakaian yang pada dasarnya mengundang kekaguman pria, di samping untuk melindungi dari udara panas yang merupakan iklim umum padang pasir. Mereka memakai kerudung, tapi kerudung tersebut sekadar diletakkan di kepala dan biasanya terulur ke belakang, sehingga dada dan kalung yang menghiasi leher mereka tampak dengan jelas. Bahkan boleh jadi sedikit dari daerah buah dada dapat terlihat karena longgar atau terbukanya baju mereka itu. Telinga dan leher mereka juga dihiasi anting dan kalung. Celak sering mereka gunakan untuk menghiasi mata mereka. Kaki dan tangan mereka dihiasi dengan gelang yang bergerincing ketika berjalan. Telapak tangan dan kaki mereka sering kali juga diwarnai dengan pacar. Alis mereka pun dicabut dan pipi mereka dimerahkan, tak ubahnya seperti wanita-wanita masa kini, walau cara mereka masih sangat tradisional. Mereka juga memberi perhatian terhadap rambut yang sering kali mereka sambung dengan guntingan rambut wanita lain. Namun setelah Islam datang, Al-Quran dan Sunnah berbicara tentang pakaian dan memberi tuntunan menyangkut cara-cara memakainya. ${ }^{9}$

Secara historis, wanita muslimah pada masa awal Islam di Madinah memakai pakaian yang sama dengan wanita umumnya, termasuk wanita tunasusila atau hamba sahaya. Mereka memakai baju dan kerudung atau jilbab, namun dada dan leher mereka terbuka, tidak jarang juga mereka memakai kerudung tapi ujungnya dikebelakangkan hingga telinga, leher, dan sebagian dada mereka terlihat. Sehingga tidak jarang orang munafik mengganggu wanita muslimah dengan mengatakan "Kami kira hamba sahaya". Dalam kondisi seperti inilah turun surat al-Ahzab [33] ayat 59 tentang pemakaian jilbab yang bermakna baju kurung yang longgar. Ayat ini secara jelas menuntut kaum muslimah untuk memakai pakaian yang membedakan mereka dengan yang bukan muslimah, ini dimaksudkan agar identitas mereka jelas, dan menghindari gangguan dari orangorang usil. ${ }^{10}$

\footnotetext{
${ }^{9}$ Quraish Shihab, Jilbab Pakaian Wanita Muslimah, (Jakarta: Lentera Hati, 2014), h. 48.

${ }^{10}$ Faisar Ananda Arfa, Wanita Dalam Konsep Islam Modernis, (Pustaka Firdaus, 2014), h. 75 .
} 
Jika menelusuri asal-usul wanita memakai cadar, cadar adalah pakaian yang digunakan untuk menutupi wajah, minimal untuk menutupi hidung dan mulut. Umat Islam di luar daerah Arab sudah mengenal cadar (niqa>b) dari salah satu penafsiran ayat Alquran di surat al-Nur [24]: 31 dan surat Al-Ahzab [33]:59 disebutkan dalam suatu riwayat bahwa Siti Saudah (istri Rasulullah) keluar rumah untuk suatu keperluan setelah diturunkan ayat hijab. Ia adalah seorang yang badannya tinggi besar sehingga mudah dikenali orang. Pada waktu itu Umar melihatnya, dan ia berkata: "Hai Saudah, demi Allah, bagaimana pun kami akan dapat mengenalmu. Karenanya cobalah pikir mengapa engkau keluar?”. Dengan tergesa-gesa ia pulang dan saat itu Rasulullah berada di rumah Aisyah sedang memegang tulang sewaktu makan. Ketika masuk ia berkata: "Ya Rasulullah, aku keluar untuk suatu keperluan, dan Umar menegurku (karena ia masih mengenalku)". Karena peristiwa itulah turun ayat ini (surat Al-Ahzab [33]: 59) kepada Rasulullah. Di saat tulang itu masih di tangannya, maka Rasulullah lalu bersabda: "Sesungguhnya Allah telah mengizinkan engkau keluar rumah untuk suatu keperluan”. Dalam riwayat lain dikemukakan bahwa istri-istri Rasulullah pernah keluar malam untuk mengqadha hajat (buang air). Pada waktu itu orangorang munafik mengganggu mereka dan menyakiti. Hal ini diadukan kepada Rasulullah sehingga Rasul menegur orang-orang munafik tersebut. Mereka menjawab: "Kami hanya mengganggu hamba sahaya". Maka turunnya ayat ini (surah Al-Ahzab [33]: 59) sebahagai perintah untuk berpakaian tertututp, agar berbeda dari hamba sahaya.

Menurut penelitian M. Qurash Shihab, memakai pakaian tertutup termasuk cadar bukanlah monopoli masyarakat Arab, dan bukan pula berasal dari budaya mereka. Bahkan menurut ulama dan filosof besar Iran kontemporer, Murtadha Muthahhari, pakaian penutup seluruh badan wanita termasuk cadar telah dikenal di kalangan bangsa-bangsa kuno, jauh sebelum datangnya Islam, dan lebih melekat pada orang-orang Persia, khususnya suku Sassan di Iran. Dibandingkan dengan di tempat-tempat lain, bahkan mereka lebih keras tuntutannya daripada yang diajarkan Islam. Sedang menurut pendapat lainnya menambahkan, orangorang Arab meniru orang Persia yang mengikuti agama Zardayst yang menilai 
37 | MUSA WA, Vol. 12 No.1 Juni $2020: 30-48$

wanita sebagai makhluk tidak suci, karena itu mereka diharuskan menutup mulut dan hidungnya dengan sesuatu agar nafas mereka tidak mengotori api suci yang merupakan sesembahan agama Persia lama. Orang-orang Arab meniru juga masyarakat Byzantium (Romawi) yang memingit wanita di dalam rumah, ini bersumber dari masyarakat Yunani kuno yang ketika itu membagi rumah-rumah mereka menjadi dua bagian, masing-masing berdiri sendiri, satu untuk pria dan satu lainnya untuk wanita. Di dalam masyarakat Arab, tradisi ini menjadi sangat kukuh pada saat pemerintahan Dinasti Umawiyah, tepatnya pada masa pemerintahan Al-Walid II (125 H/747 M), di mana penguasa ini menetapkan adanya bagian khusus buat wanita di rumah-rumah.

Seperti yang telah disinggung sebelumnya, bahwa pakaian tradisional dan budaya Arab itu tidak memakai cadar, bahkan ada yang tidak berkerudung sehingga terlihat rambut mereka. Ada juga di antara tayangan yang berseliwerang di internet yang membuktikan hal ini. ${ }^{11}$

Jadi praktik bercadar -sekali lagi- adalah bentuk respon dari turunnya ayat hijab. Di antara yang menegaskan hal tersebut, ada riwayat dari Aisyah mengatakan:

"Ketika turun ayat ini, yaitu: 'Dan perintahkanlah agar mereka menjulurkan kain kerudung mereka hingga dada-dada mereka', mereka langsung mengambil kainkain mereka dan merobek ujung-ujungnya, maka mereka berkhimar dengannya”. Ibnu Hajar Al-'Asqalany lalu menjelaskan maksud "mereka berkhimar dengannya" dengan berkata:

"Yaitu menutup wajah-wajah mereka". ${ }^{12}$ Demikian di antara dalil-dalilnya.

Dari semua uraian yang disajikan, adalah jawaban tegas tudingan sementara orang yang "menuduh" cadar merupakan budaya Arab. Pada saat yang sama, mengesankan bahwa cadar bukan syariat Islam. Padahal para ulama kita telah membahas hukum penggunaan cadar. Dalam Islam, cadar -terlepas perbedaan pendapat yang ada- telah ada tuntunannya, sebagaimana yang akan diuraikan pada bahasan selanjutnya. Sehingga menurut hemat penulis, cadar

\footnotetext{
${ }^{11}$ Di antaranya, https://youtu.bel_lruY7yUGDg

${ }^{12}$ Fathul Bary 8/490
} 
adalah syariat; ada tuntunannya dalam ajaran Islam. Kendati boleh jadi, cadar ini telah membudaya di sebagian negara Arab.

\section{Hukum Bercadar}

Berbicara hukum Islam, tentu akan selalu merujuk pada empat mazhab fiqih yang telah populer di kalangan masyarakat. Kendati pada faktanya, paling tidak ada delapan mazhab fiqih yang masih eksis hingga saat ini. ${ }^{13}$

Hukum cadar bagi wanita termasuk pembahasan fiqih yang diperselisihkan (khilafiyah) di kalangan ulama. Perbedaan ini berkisar antara hukum wajib, sunnah, mubah, makruh dan haram. Mungkin ketika mendengar hukum wajib dan sunnah dalam urusan cadar, tidak lagi aneh di telinga kita. Namun bagaimana dengan hukum makruh dan haram?

Perbedaan pendapat ulama ini tentu tentu tidak bisa dilepaskan dari banyak faktor. Salah satunya adalah batasan aurat bagi wanita. Apakah wajah termasuk aurat yang wajib ditutup ataukah bukan termasuk aurat? Kedua, faktor keadaan dan kondisi. Kapan saja wanita dilarang bercadar?

Tentu saja faktor-faktor yang menyebabkan perbedaan ini tidak hanya “yang penting beda". Namun tentu saja ada dalil-dalil yang diusung dan dijadikan sebagai landasan berpendapat mereka.

Terakhir, terlepas dari semua perbedaan-perbedaan tersebut, bahwa pakaian wanita muslimah semakin tertutup dan rapi, maka akan semakin baik dan sempurna dari sisi penjagaan terlihatnya aurat. ${ }^{14}$

Dari faktor-faktor yang telah disebutkan sebelumnya, bisa disimpulkan hukum cadar bagi wanita, terbagi ke dalam beberapa pendapat ulama berikut ini:

\section{Jumhur Ulama}

Secara umum, jumhur fuqaha dari empat mazhab berpendapat bahwa wajah wanita bukan aurat. Karena bukan aurat, maka boleh dibuka boleh juga ditutup cadar. Artinya, hukum cadar menurut jumhur adalah mubah. Baru nanti akan

${ }^{13}$ Yaitu Mazhab Hanafi, Maliki, Syafi'I, Hanbali, Ja'fary/Itsna 'Asyariyah, Zaidiyah, AzZahiriyah dan Al-Ibadhiyah. Baca: Quraish Shihab, Islam yang Saya Anut, Cet I (Tangerang: Lentera Hati, 2018), h. 13-18.

${ }^{14}$ www.rumahfiqih.com/pdf/x.php?id=144 
39|MUSA WA, Vol. 12 No.1 Juni $2020: 30-48$

berkembang sesuai dengan kondisi. ${ }^{15}$ Sejalan dengan pendapat ini, Prof. Dr. Ali Jum'ah menyatakan bahwa memakai niqab atau penutup wajah adalah pekerjaan opsional (bebas). Tidak diperintahkan dan tidak juga dilarang.

2. Hanafiyah

Secara khusus mazhab Hanafiyah mengatakan, pada zamannya, wanita muda dilarang menampakkan wajahnya di hadapan laki-laki asing (bukan mahram). Bukan karena alas an aurat, tapi karena khawatir terjadi fitnah. Artinya, jika membuka wajah itu tidak menimbulkan fitnah, maka tidak perlu ditutup dengan cadar.

3. Malikiyah

Sedangkan kalangan Malikiyah justru menganggap hukum cadar adalah makruh. Baik di dalam maupun di luar salat. Karena bercadar dianggap perbuatan yang berlebihan. Pendapat lain dari Malikiyah menyebutkan bahwa menutup wajah (cadar) dan telapak tangan hukumnya wajib bagi wanita yang dikhawatirkan bisa menimbulkan fitnah karena kecantikannya.

4. Syafi'iyah

Dalam mazhab Syafi'iyah sendiri terjadi perbedaan pendapat terkait hukum cadar. Sebagian menganggap wajib, sebagian lain menganggap sunnah. Perbedaan ini seseuai keadaan.

5. Hanabilah

Hanya mazhab Hanbali yang berpendapat bahwa seluruh tubuh wanita, termasuk wajah adalah aurat. Oleh sebab itu, di luar salat hanya mazhab Hanbali yang mewajibkan menutup wajah bagi wanita dengan menggunakan cadar. Namun dalil-dalil dari mazhab ini telah dibantah oleh jumhur ulama. Sehingga pendapat yang kuat adalah pendapat jumhur, sebagaimana poin pertama.

6. Abdullah Ibn Baz

Di dalam salah satu fatwanya yang ditayangkan di website resminya, beliau mengatakan secara tegas bahwa cadar bagi wanita adalah wajib. Membuka wajah di hadapan laki-laki yang bukan mahram (ajnaby) adalah sebuah

\footnotetext{
${ }^{15}$ Ahmad Hilmi, op.cit., h. 13.
} 
kemaksiatan. Menurutnya, kata jilbab dalam QS. Al-Ahzab:59 dimaknai sebagai model pakaian yang bisa menutup seluruh tubuh wanita beserta wajahnya. Ini berarti kata cadar masuk dalam jilbab. ${ }^{16}$

Adapun bercadar dalam kondisi ihram (haji ataupun umrah), seluruh ulama sepakat bahwa wanita yang berihram haram menutup wajah mereka menggunakan cadar. Pendapat ini didasari oleh hadis yang diriwayatkan oleh Ibn Umar:

"Janganlah wanita yang sedang berihram menggunakan cadar, jangan pula menggunakan sarung tangan”. (HR. Bukhary).

Ihramnya wanita dengan cara membuka wajahnya. Jika dia menutupinya dengan cadar tanpa adanya kebutuhan (hajat), maka dia terkena dam/diyat. Sebagaimana diyat yang dibebankan kepada laki-laki yang berihram dan menutup kepalanya dengan topi atau peci.

Namun ada pengecualian bolehnya juga menutupi wajahnya ketika di hadapan laki-laki atau bahkan bisa menjadi wajib jika diyakini dapat menimbulkan fitnah apabila wajah tidak ditutup. Salah satunya karena faktor kecantikan. Pengecualian ini berdasarkan hadis dari Aisyah:

"Aisyah berkata: Para pengendara lewat di hadapan kami, dan kami bersama Rasulullah dalam keadaan berihram. Ketika para pengendara itu mendekat, maka seorang dari kami menjulurkan jilbabnya dari arah kepala menuju wajahnya. Ketika sudah berlalu, maka kami membukanya kembali”. (HR. Abu Daud).

Hadis kedua tentang pengecualian menutup wajah, dari Fatimah binti Mundzir, beliau berkata:

"Dulu kami menutup wajah dalam keadaan ihram. Dan kami ketika itu bersama dengan Asma binti Abi Bakr”. (HR. Malik dan Al-Hakim).

Imam Al-Baji dalam Syarh Al-Muwattha berkomentar tentang hadis di atas, bahwa yang dimaksud menutup wajah adalah menutup yang bersifat insidental, ketika dibutuhkan. Bukan bermakna cadar yang selalu dipakai sepanjang ihram.

\footnotetext{
${ }^{16}$ Ahmad Hilmi, op.cit., h. 13-14.
} 
41 | MUSA WA, Vol. 12 No.1 Juni $2020: 30-48$

Adapun syarat pengecualian penutup wajah ketika ihram, menurut beragam pandangan ulama, sebagai berikut:

1. Hanafiyah dan Syafi'iyah

Hanafiyah dan Syafi'iyah menetapkan syarat bolehnya wanita menutup wajah ketika ihram. Syarat tersebut adalah agar kain penutup tidak langsung menempel pada wajah, dengan memberinya semacam penyangga, agar menjadi seperti payung. Pendapat ini pun dipilih sebagai pendapat mazhab Hanbali.

2. Malikiyah

Kalangan Malikiyah tetap membolehkan kain menempel wajah dengan cara sekedar menjulurkan kain jilbab dari atas kepala untuk menutup wajah pada kondisi yang dibutuhkan. Bukan cadar secara khusus dengan cara mengikat atau menempelkannya dengan jarum. ${ }^{17}$

Selanjutnya, hukum bercadar ketika/dalam salat, adalah sebagai berikut:

1. Makruh

Jumhur ulama berpendapat bahwa bercadar dalam salat hukumnya makruh. Sedangkan di luar salat hukumnya boleh.

Malikiyah berpendapat cadar makruh dalam segala kondisi, dalam salat maupun di luar salat. Kecuali jika cadar merupakan kebiasaan atau tradisi, maka di luar salat tidak makruh.

Sedangkan Syafi'iyah berpendapat bahwa cadar makruh dalam kondisi salat.

Adapun Hanabilah, juga berpendapat makruh bercadar dalam salat jika tidak ada kebutuhan yang mendesak. Ibn Abdi Al-Barr mengatakan, bahwa para ulama sepakat perempuan wajib membuka wajahnya ketika salat dan ihram. Karena dengan bercadar menyebabkan terhalangnya wajah dan menutup mulut.

2. Haram

Begitupun mazhab Hanafiyah berpendapat hukum cadar adalah makruh di dalam salat. Argumentasi yang dibangun oleh Hanafiyah dalam memakruhkan

\footnotetext{
${ }^{17}$ Ahmad Hilmi, op.cit., h. 15-17.
} 
cadar dalam salat adalah karena menyerupai kaum Majusi yang menutup wajahnya ketika menyembah api. Kemakruhan yang dimaksud oleh Hanafiyah adalah makruh tahrim. ${ }^{18}$

\section{Cadar Indikasi Radikal?}

Menurut mantan Menteri Agama Republik Indonesia, Lukman Hakim, radikal berasal dari kata radiks yang berarti mengakar atau mendalam. Sementara, dari sudut pandang agama, memahami serta mengamalkan suatu ajaran agama secara mendalam dan mengakar memang sudah semestinya dilakukan oleh masing-masing pemeluk. Dalam konteks keberagamaan, radikalisme sebetulnya bukan sesuatu yang harus dicegah karena semua agama memang pada dasarnya mengajarkan setiap pemeluknya untuk memegang agama secara mengakar dan mendalam. Akan tetapi, kata dia, yang perlu diperangi bersama-sama adalah akses negatif yang muncul dari penyikapan sesuatu yang radikal tersebut yang diwujudkan dengan pemaksaan kehendak dengan menghalalkan segala cara. "Sehingga tatharruf atau ekstrimisme atau pemaksaan kehendak itulah yang perlu dicegah, bukan radikalnya," kata dia. ${ }^{19}$

Sedang radikal menurut Badan Nasional Penanggulangan Terorisme (BNPT), Kepala Humas dan Pusat Informasi BNPT, Irfan Idris, mengatakan setidaknya ada empat hal ciri radikalisme. Kriteria pertama, yakni radikalisme bisa ditimbulkan dari ingin melakukan perubahan dengan cepat menggunakan kekerasan mengatasnamakan agama. Kedua, mengkafirkan orang lain. Ketiga, mendukung, menyebarkan dan mengajak bergabung dengan ISIS. Keempat, memaknai jihad secara terbatas. ${ }^{20}$

Ada juga sebagian yang mendefinisikan radikalisme dengan memposisikannya dengan lawannya, yaitu moderat atau moderasi, yang dalam

\footnotetext{
${ }^{18}$ Ahmad Hilmi, op.cit., h. 19-20.

19 https://www.republika.co.id/berita/dunia-islam/islam-nusantara/15/10/28/nwxugn313menag-pisahkan-istilah-radikalisme-dari-ekstrimisme

${ }^{20}$ https://www.republika.co.id/berita/nasional/umum/15/03
} 
43 | MUSA WA, Vol. 12 No.1 Juni $2020: 30-48$

bahasa Arab sering digunakan istilah al-wasathiyah (الوسطية). ${ }^{21}$ Memang, radikal yang dimaksud dari sub bahasan ini, cenderung pada pengertian yang ketiga.

"Irisan antara radikalisme dengan bukan radikalisme sangat tipis walaupun sebenarnya amat nyata. Mirip dengan garis di lapangan hijau yang kadang pemain bola lengah. Di lapangan bola seringkali para pemain yang lagi berkonsentrasi pada permainan tanpa sadar melewati garis off-side. Sehingga terkena semprit wasit atas informasi hakim garis. Hal itu menyebabkan gol yang dihasilkannya menjadi tidak sah dan dianulir. Hal semacam itu bukan karena garisnya tidak ada. Garisnya ada dan cukup jelas terlihat oleh para penonton. Akan tetapi seringkali justru para pemainnya yang tidak menyadari bahwa dirinya telah melakukan pelanggaran. Begitulah sprotifitas dalam sepakbola. Pemain yang kena semprit wasit tidak punya pilihan kecuali hanya pasrah saja. Lain halnya dengan di tengah lapangan dakwah Islam. Sudah garis off-sidenya tidak ada, hakimnya pun tidak ada juga. Maka tidak pernah ada off-side, bahkan tidak ada rule of the game sama sekali". 22

Berangkat dari ucapan Ahmad Sarwat di atas, menggolongkan cadar sebagai indikasi radikal menjadi perkara dilematis. Hal ini bukan tanpa alasan, sebab fakta di lapangan semakin menguatkan asumsi ini. Di satu sisi, peristiwa teror atau bom bunuh diri yang kerap terjadi di Indonesia, istri para pelakunya ada yang bercadar. Di sisi lain, masih banyak wanita muslimah Indonesia yang juga bercadar, namun pemahaman dan pengamalannya akan Islam sangatlah baik. Benar-benar mencitrakan Islam sebagai rahmatan lil 'alamin.

Sehingga, diperlukan kehati-hatian, sebab perkara ini adalah perkara yang sensitif. Gegabah dan keliru dalam menyimpulkan, dapat menyulut amarah masyarkat. Untuk itu, diperlukan jalan tengah dalam menyikapi hal ini.

Cadar menjadi ciri atau gejala bagi muslimah yang terpapar radikalisme, ketika ia mengekslusifkan diri dengan pakaiannya itu. Bahkan mencibir atau menyalahkan muslimah lain yang tak memakai cadar, karena menganggap cadar sebagai ukuran ketakwaan. Prof. Dr. Ali Jum'ah berkata, "Kami berpendapat

\footnotetext{
${ }^{21}$ Ahmad Sarwat, Islam Radikal, (Jakarta Selatan: Rumah Fiqih Publishing, 2019), h. 12.

${ }^{22}$ Ahmad Sarwat, op.cit., h. 8-9.
} 
bahwa tindakan menutup wajah apabila dijadikan sebagai alasan untuk hidup ekslusif, terpisah dari komunitas masyarakat luas, atau sebagai syiar dalam beribadah dan beragama, maka hukumnya telah keluar dari sunnah dan mubah, dan menjadi bid'ah yang terlarang". 23

Namun memukul rata atau menggenaralisir cadar sebagai indikasi radikal juga tidaklah tepat. Sebagaimana yang telah disinggung sebelumnya, masih banyak muslimah lain yang bercadar, namun juga berakhlak dengan baik. Selama muslimah yang bersangkutan memakai cadar pada lingkungan yang tepat.

\section{Larangan Penggunaan Cadar, Tepatkah?}

Sejatinya pelarangan cadar sudah diberlakukan di berbagai negara di dunia. Bahkan negara yang banyak penduduknya muslim pun ada yang memberlakukan pelarangan cadar. Beberapa negara yang melarang penggunaan cadar memiliki banyak pertimbangan. Mulai dari alasan keamanan, membatasi ideologi radikal, merawat tradisi, hingga mengedepankan asas kehidupan bersama. Bahkan jika ada warga negaranya yang nekat memakai cadar, mereka dikenakan denda atau dipenjara.

Seperti dilansir dari NU Online dikutip dari laman DW dan BBC, setidaknya ada 14 negara yang melarang pemakaian cadar, niqab, burka, atau sejenisnya. Yaitu: Maroko, Tunisia, Chad, Prancis, Belgia, Belanda, Denmark, Jerman, Austria, Bulgaria, Norwegia, Tajikistan, Sri Lanka, dan China. Demikian lansir Okezone.com $(04 / 11 / 2019) .^{24}$

Di Indonesia sendiri, pada bulan Februari 2018, masyarakat dihebohkan dengan berita tentang larangan bercadar bagi mahasiswi yang kuliah di UIN Sunan Kalijaga Yogyakarta. Ini berdasarkan Surat Rektor No B1301/Un02/R/AK.00.3/02/2018 tentang Pembinaan Mahasiswi Bercadar. Kasus yang mirip, terjadi juga di IAIN Bukittinggi berkaitan dengan dinonaktifkannya dosen bahasa Inggris bernama Dr. Hayati Syafri, S.S, M.Pd. terhitung mulai

23 Ali Jum'ah, Menjawab Dakwah Kaum Salafi, Cet II (Jakarta Selatan, KHATULISTIWA Press, 2017), h. 226-227.

${ }^{24} \mathrm{https}: / /$ muslim.okezone.com/read/2019/11/04/614/2125613/ 
45 | MUSA WA, Vol. 12 No.1 Juni $2020: 30-48$

Februari 2018 karena bercadar. Rektor IAIN Bukittinggi, Ridha Ahida menyatakan bahwa aturan tentang larangan bercadar di kampus itu berdasarkan otonomi kampus. ${ }^{25}$

Sehingga berangkat dari fakta di atas, tepat tidak tepatnya pelarangan cadar tentu bersifat kondisional. Jika suatu wilayah, negara, atau instansi, dengan beragam pertimbangan mendukung hal tersebut, maka tidak masalah jika harus menerapkan pelarangan cadar. Begitu pula sebaliknya, jika tidak ada pertimbangan yang mendukung, maka tidak ada alasan untuk melarangnya. Sebab baik secara hak asasi maupun tuntunan agama, bercadar adalah perkara yang dibolehkan.

Dalam konteks wacana pelarangan cadar oleh Menteri Agama, ada banyak kritik dan saran yang masuk sebagai respon dari kebijakan ini. Sehingga, penting bagi Pak Menteri untuk meninjau kembali dan memikirkan secara matang rencananya tersebut. Kendati sampai tulisan ini dirilis, tampaknya kebijakan tersebut masih sebatas wacana. Begitu pun sebagai aturan negara, sependek pengamatan penulis, Indonesia belum sampai pada tahap untuk menerapkan pelarangan cadar bagi warganya. Terkait isu radikalisme, rakyat masih bisa menaruh kepercayaan terhadap BNPT (Badan Nasional Penanggulangan Terorisme) untuk menanggulanginya.

\section{Bijak Menyikapi Cadar}

Pada prinsipnya, cadar adalah perkara yang dibolehkan. Sehingga menyikapi cadar, diperlukan sikap yang moderat lagi bijak. Bagi penggunanya, agar tidak mengekslusifkan diri dengan cadarnya. Tidak mencibir atau menyalahkan muslimah lain yang tidak memakai cadar. Betul-betul berangkat dari keyakinannya tentang hukum bercadar, apa sebatas mubah atau sunnah, tidak lebih. Juga memakai cadar pada lingkungan yang tepat. Jika berada pada lingkungan masyarakat dan budaya yang menganggap cadar tergolong aneh, maka

${ }^{25}$ Toha Andiko, Larangan Bercadar di Perguruan Tinggi Perspektif Sadd Al-Dzariah. (Bengkulu, 2018/pdf). 
dianjurkan untuk melepas cadarnya sementara waktu. Begitu pula, jika seorang muslimah yang aslinya tidak memakai cadar, namun suatu waktu ia berada di wilayah atau negara yang mengenal tradisi cadar, maka tak mengapa ia mengenakan cadar dan menaati tradisi masyarakat setempat. ${ }^{26}$

Bagi pemerintah, perlu ekstra waspada dalam mengeluarkan kebijakan terkait cadar. Jika memang harus melarang, agar memperjelas alasannya, pada lingkup apa pelarangannya dan memastikan sosialisasinya terlebih dahulu kepada khalayak. Menghindari untuk mengaitkan alasan pelarangan cadar dengan sesuatu yang melanggar kebebasan dalam pengamalan agama, atau hal sensitif lainnya. Sehingga tidak memantik kegaduhan, yang pada dasarnya masyarakat kita masih banyak yang mudah tersulut emosinya.

Bagi akademisi, agar tidak memperkeruh suasana dengan memprovokasi masyarakat. Pemahaman dan sikapnya, idealnya betul-betul bisa mencerminkan sebagai seorang akademisi. Semestinya setingkat atau bahkan bertingkat-tingkat diatas masyarakat awam dalam menyikapi sesuatu, termasuk perkara cadar. Serta turut berkontribusi, ikut membantu memahamkan masyarakat yang belum paham dan yang masih terjebak dalam kegaduhan.

Bagi masyarakat umum, agar bisa lebih bersabar dalam menyikapi sesuatu. Tidak mudah terprovokasi dan selalu mengedepankan tabayyun dalam menyerap informasi. Memandang cadar sebagai kebebasan dalam mengamalkan agama, di mana hal tersebut telah bernaung di bawah payung konstitusi. Memandang cadar sebagai bagian dari kekayaan khazanah pakaian Indonesia, yang terbingkai dalam Bhineka Tunggal Ika.

Terakhir, polemik yang semacam ini sudah menjadi sunnatullah, yang biasa disebut hukum alam atau hukum kemasyarakatan. Dalam arti, akan selalu muncul orang yang kurang atau tidak memahami persoalan ini. Sehingga bukan tidak mungkin, kegaduhan tentang cadar bisa muncul kembali di masa yang akan datang. Selanjutnya tinggal memilih, ingin mencipta gaduh itu atau menjadi solusi? Sekian, wallahu a'lam.

26 Ali Jum'ah, Menjawab Dakwah Kaum Salafi, Cet II (Jakarta Selatan, KHATULISTIWA Press, 2017), h. 226. 
47 | MUSA WA, Vol. 12 No.1 Juni $2020: 30-48$

\section{KESIMPULAN}

Cadar adalah penutup wajah bagi kaum wanita. Baik yang menutupi wajah keseluruhan (di bagian mata, kain dengan tembus pandang), kecuali mata, atau hanya sebagian saja (sekadar hidung dan mulut/mulai di bawah mata menjulur ke bawah).

Pada prinsipnya cadar bukan budaya Arab dan termasuk syariat. Dalam arti telah diatur hukumnya dalam Islam, kendati masih terjadi khilafiyah. Cadar memang bukan budaya Arab, namun boleh jadi cadar telah membudaya pada sebagian negara Arab, atau bahkan di negara nonarab.

Secara umum, jumhur fuqaha dari empat mazhab berpendapat bahwa wajah wanita bukan aurat. Karena bukan aurat, maka boleh dibuka boleh juga ditutup cadar. Artinya, hukum cadar menurut jumhur adalah mubah. Baru nanti akan berkembang sesuai dengan kondisi. Memakai niqab atau penutup wajah adalah pekerjaan opsional (bebas). Tidak diperintahkan dan tidak juga dilarang.

Tak tepat jika menggenaralisir cadar sebagai indikasi radikal. Hanya perlu mengenali, bahwa cadar adalah salah satu ciri atau gejala radikalisme jika muslimah yang bersangkutan mengekslusifkan diri dengan cadarnya, serta menjadikan cadar sebagai ukuran keimanan dan ketakwaan.

Begitu pula, tepat tidak tepatnya pelarangan cadar tergantung pada kondisi yang berlaku pada suatu negara, wilayah, atau instansi. Diperlukan pertimbangan dan pengamatan yang matang, serta mendengar masukan dan aspirasi yang berkembang di tengah masyarakat sebelum betul-betul menerapkan hal tersebut.

Akhirnya, diperlukan kerjasama tiap eselon masyarakat dalam memandang setiap persoalan yang muncul, khususnya terkait cadar ini. Berkepala dingin dan bijak dalam menyikapinya, sehingga mampu mencegah terjadinya hal-hal yang tidak diharapkan. 


\section{DAFTAR PUSTAKA}

Al-Qur'a>n Al-Kari>m

Al-Asqalany, Ahmad bin Ali bin Hajar. 2001. Fath al-Bary. Riyadh: Maktabah alMulk Fahd al-Wathaniyyah.

Andiko, Toha. 2018. Larangan Bercadar di Perguruan Tinggi Perspektif Sadd AlDzariah. Bengkulu: (pdf).

Arfa, Faisar Ananda. 2014. Wanita Dalam Konsep Islam Modernis. Pustaka Firdaus.

Hilmi, Ahmad. 2019. Hukum Cadar Bagi Wanita. Jakarta Selatan: Rumah Fiqih Publishing.

Jum'ah, Ali. 2017. Menjawab Dakwah Kaum Salafi. Jakarta Selatan: KHATULISTIWA Press.

Kamus Besar Bahasa Indonesia

Sarwat, Ahmad. 2019. Islam Radikal. Jakarta Selatan: Rumah Fiqih Publishing.

Shihab, Muhammad Quraish. 2018. Islam yang Saya Anut; Dasar-Dasar Ajaran Islam. Tangerang: Lentera Hati.

Shihab, Muhammad Quraish. 2014. Jilbab Pakaian Wanita Muslimah. Jakarta: Lentera Hati.

Shihab, Muhammad Quraish. Wawasan Al-Quran. Tangerang: Lentera Hati. 